Ethiopian Journal of Environmental Studies \& Management 10(2): 137 - 150, 2017.

ISSN:1998-0507

Submitted: May 18, 2016

doi: http://dx.doi.org/10.4314/ejesm.v10i2.1

Accepted: February 16, 2017

\title{
FOREST DEGRADATION AND LIVELIHOOD: A CASE STUDY OF GOVERNMENT FOREST RESERVES OF OGUN STATE, NIGERIA
}

\author{
*OLAREWAJU, T.0., ${ }^{1}$ ORUMWENSE, L.A., ${ }^{1}$ AGBOR, C.F. ${ }^{2}$ AND AWE, F. ${ }^{1}$ \\ ${ }^{1}$ Department of Forest Economics and Extension Services, Forestry Research Institute of \\ Nigeria, Jericho Hills P.M.B, 5054 Ibadan, Oyo State, Nigeria \\ ${ }^{2}$ Department of Environmental Modelling and Biometrics, Forestry Research Institute of \\ Nigeria, Jericho Hills P.M.B, 5054 Ibadan, Oyo State, Nigeria
}

\begin{abstract}
This study examined the effect of forest degradation on livelihood returns in Government forest reserves of Ogun State. Primary data used in the study were obtained in a multistage random sampling procedure across non-degraded and degraded forests. Both qualitative and quantitative analytical methods were employed for data analysis. Different forest based livelihood and returns were investigated in this study and the Levene's test results showed that there is disparity in the livelihood returns across the nondegraded and degraded forests. Logistic regression results revealed that gender, number of household members working and earning income, number of children in the household, earning income from tree crops and earning income from hunting were statistically significant factors influencing forest degradation within the study area. Therefore, the study recommends that strong and participatory forest management practices should be encouraged to ensure that tree crop farming and hunting are monitored and done without hurting the forest.
\end{abstract}

Key Words: Forest degradation, Livelihood returns, Government Forest Reserve, Ogun State

\section{Introduction}

Forests have sustained human needs world over for centuries and people have harvested fuelwood, fodder, other plant materials, hunted wild animals for meat and grazed their livestock in forests (Mehta et al., 2008; Arjunan et al., 2005; Harris and Mohammed, 2003). Millions of households in developing countries, Nigeria inclusive therefore depend on forests for its products and benefits which they also harvest, process and trade in to generate income (Tewari, 2012). Forest has been known to be a source of livelihood all over the world particularly for resource poor people who are living close to and within the forests. Livelihood as defined by Chambers (1995) is the means of gaining of living. It is the activities that generate food and income that can be used in purchase of other goods and services required for

*Corresponding Author: Olarewaju, T.O.

Email: titiquadri@yahoo.com 
Forest Degradation and Livelihood................0LAREWAJU et al.

decent living. This also includes tangible and intangible assets relied upon for living. However, with the poor having little or no tangible assets which sometimes beget the intangible assets, they are left with the environmental assets when use and access to such is not restricted (World Resources, 2005). Several rural communities depend on and use a variety of forest products. The uses ranges from direct consumption of forest products and services to collection of forest products for sale as well as the use of forest products for food security in times of seasonal shortages, drought and economic stress. Expressly, forest products such as edible fruit, flowers, tubers, roots and leaves are consumed as food and medicine, others such as timber are used for construction and fencing, fodder are harvested and fed to livestock while some directly graze their livestock in the forest, firewood are used for cooking or sold in the market to generate income (Banerjee and Madhurima, 2013). Non-timber forest products (NTFPs) e.g. snails, games, leaves, mushrooms are also as a major source of income for the rural communities who have access to forest. It is thus clear that aside the use of forest products for livelihood support and risk management, forests are potentially valuable to rural people as means of income generation and poverty reduction (Onuche, 2011). However, the increase in human density near and within the forested areas has been noted to contribute to forest degradation, loss of biodiversity and forest cover (Davidar et al., 2010; Karanth et al., 2006).

Forest degradation refers to changes within the forest class (Tavani et al., 2009). It is a condition of the forest that results in its inability to provide optimum goods and services. This situation is different from deforestation which is the total conversion of forest to a permanent land use outside of forestry. A degraded forest therefore is still a standing forest with reduced production capacity while a deforested area is a place having forest in the past as against a no standing forest at a particular time of reference. Extraction of forest for livelihood can potentially degrade forest if harvest is done unsustainably or beyond the carrying capacity of the forest. Evidences abound in literature that the pattern of collection of forest products particularly for livelihood support has been a major cause of degradation (Sagar and Singh, 2004; Maikhuri et al., 2001; Silori and Mishra, 2001). Hence, the livelihood concerns of the millions of poor people living in and around forest contribute to forest degradation along with other factors. Although the forest has the potential to alleviate poverty and food insecurity but the present rate of extraction is contributing to degradation which in turn reduces the production capacity of the forest. Owing to the widespread dependence of huge population on forest for subsistence livelihood, it is pertinent that this livelihood threatening situation be arrested through the design and implementation of relevant policies. However, economic values losses that forest degradation impact on livelihood is scarce in literature. This is essential for both the government and the rurals concerned as economic values of forest degradation will communicate the extent of havoc that forest degradation is causing on livelihood and thereby further deepening poverty. The exposure of factors that contribute to forest degradation needs to be known so as to 
abate such and stop further degradation of the forest. Thus, the causes of forest loss and degradation need to be identified to formulate better management and policy decisions. Owing to the above, this study provided the determinants of forest degradation. Specifically the study showed the contribution of forest to livelihood and income and also investigated the factors that influenced forest degradation.

\section{Study Area}

The study area is Ogun State, Nigeria with coordinates $6.9098^{\circ} \mathrm{N}$ and $3.2584^{\circ}$ E. The geology and relief of Ogun State is dominated by sedimentary rocks in the south and basement complex rocks in the north. The former underlies approximately three-quarters of the Ogun State surface area stretching from the north-west to the south-west, while the latter covers the rest of the state. As a result of these geological attributes, a number of mineral resources are associated with the state, and these are grouped into the metalliferous minerals (iron ore), the non-metalliferous minerals (kaolin, limestone, brick clays, sandstone, silica sands, etc.) and the energy resources (tar sand and radiometric phosphate). The important elevated areas of the state are found around Abeokuta (ie. Olumo Rock). The perennial rivers are Ogun, Oshun, Yewa, Yemoja, Ona, Sas, Oni, Ohun, Ohia, Abafon, Oyan and Iju. Three broad groups of soil cover the state. These are ferruginous tropical soil which spreads across much of the Egbado North and the Odeda Local Government Area (LGA), the hydromorphic soil which covers mainly the coastal areas of Ogun Waterside and the Yewa South LGA, and the ferralitic Soil which covers the rest of the state. Ogun State is categorized to be in the humid tropical climatic zone. Two major vegetation groups dominate the state's territorial space. These are the Savannah and the Forest. The Savannah is of the derived type covering much of the Yewa North and the Abeokuta LGA. The forest of Ogun state is of two types. These are the fresh water swamp forest found in the coastal areas of Ogun Waterside and the Egbado South LGA, and the lowland rain forest which covers the rest of the state (Adamson, 1996). 
Forest Degradation and Livelihood................. OLAREWAJU et al.

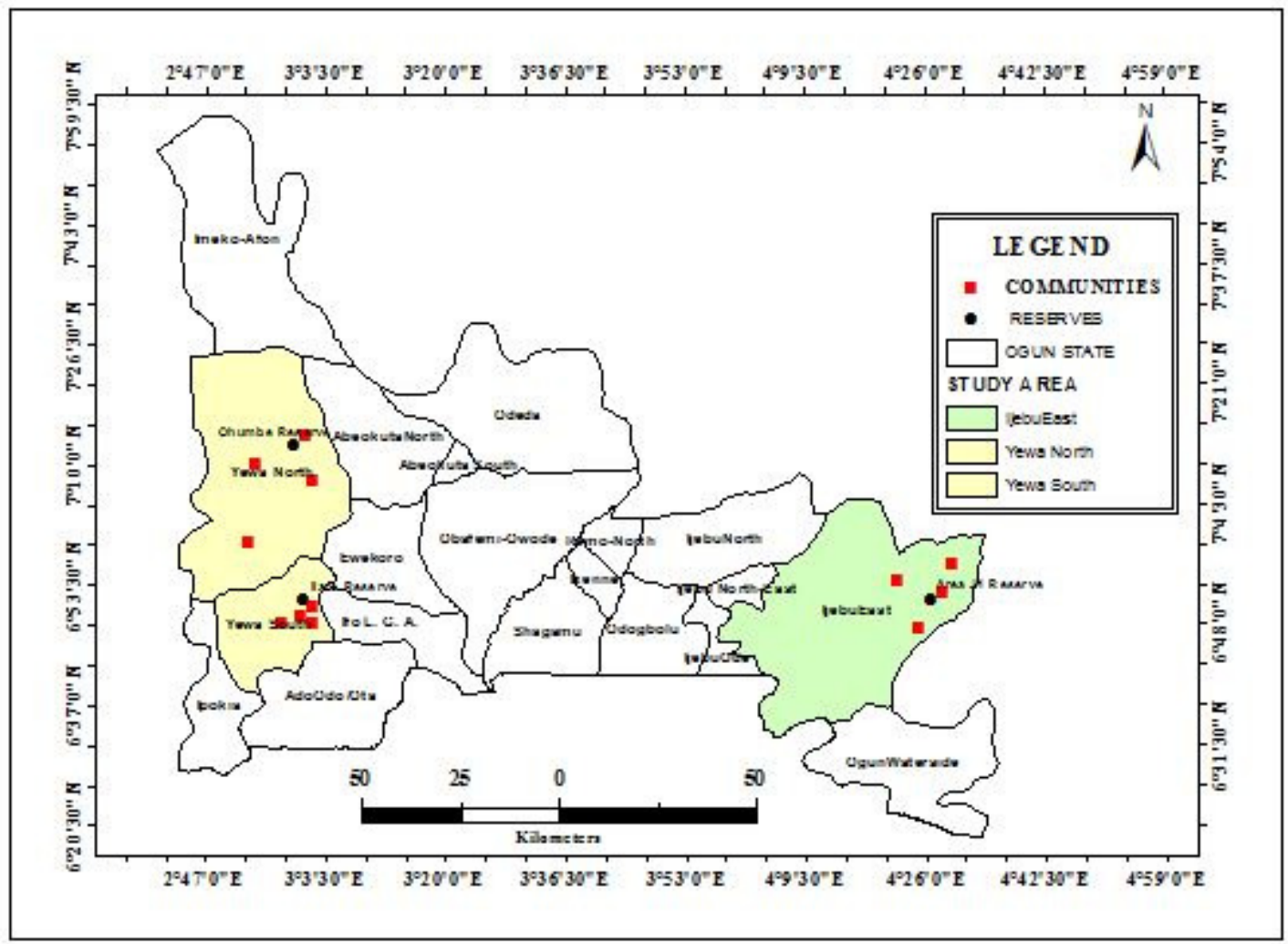

Figure 1: Map of Study Area

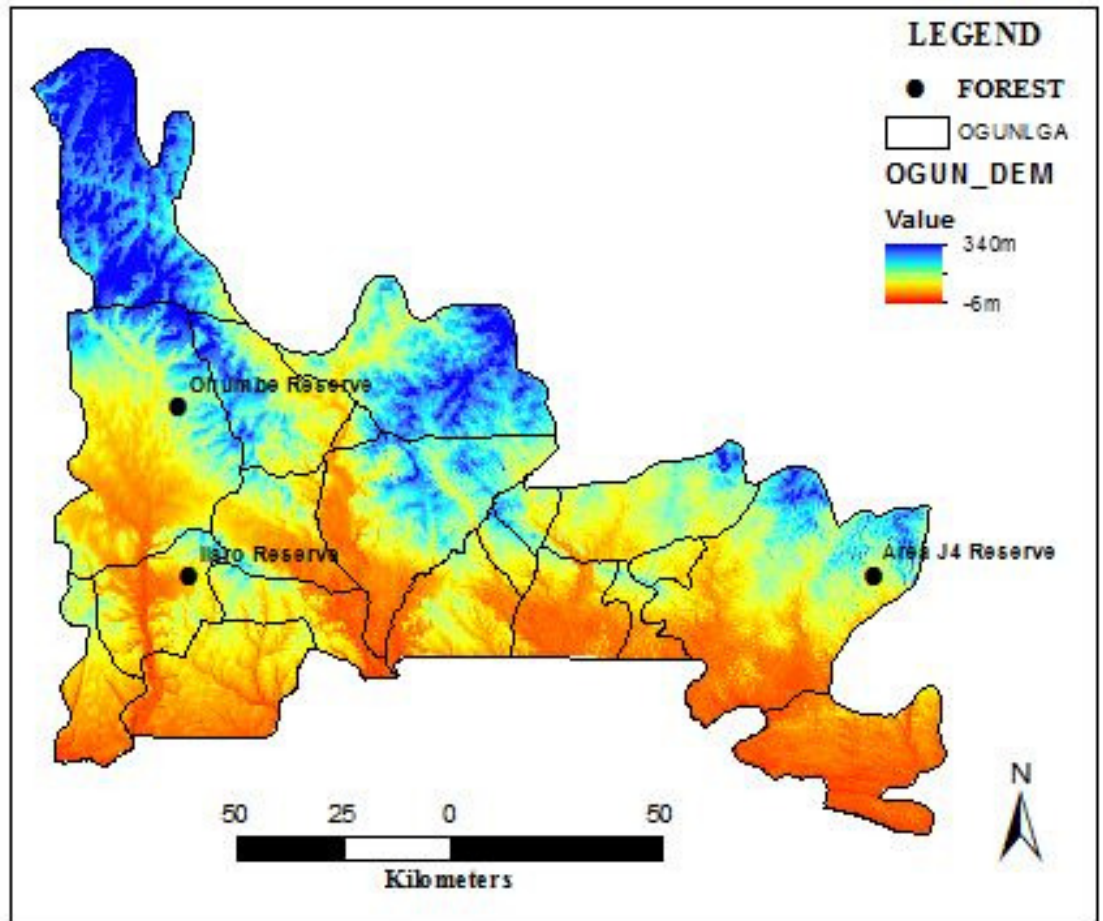

Figure 2: The Relief of the Study Area derived from SRTM image 


\section{Methodology}

Multistage sampling technique was used in this study. Stage one involved the stratification of forest along type and forest state (degraded and non degraded forest) as delineated by the Ogun State (Ogun State Ministry of Forestry, 2014). Stage two involved the purposive selection of communities around the fresh water swamp (Ilaro and Oja Odan) and lowland rain forest (J4). Ilaro is located in Yewa south, oja Odan in Yewa North while Area J4 lies within Ijebu East and North of Ogun state. The third stage involved the random selection of two communities around the forest reserves while the fourth stage involved random selection of crop farmers proportionately to size of the communities making a total of 167 respondents. Data collection was done through the use of well-structured questionnaires. Frequency counts, percentages, Levene's test of equality of variances and logistic regression model were employed in analysing the data.

\section{Levene's test of equality of variances}

The test for equality of variances is used to compare the variances associated with mean values of a variable across two groups. This test falls under the broad category of independent-samples $\mathrm{T}$ test procedure that compares means for two groups. The test is suitable in cases where the subjects were randomly assigned to two groups, so that any difference in response is due to the treatment (or lack of treatment) and not to other factors. Here differences in return to different livelihood were premixed on the state of the forest itself. Hence, the Levene test of equality of variances (Blalock, 1972) was employed for this purpose. The Levene statistic tests whether there is significant difference in the return to different livelihood in the degraded and nondegraded forest. The test statistics is defined as:

$L=\frac{(w-2) \sum_{k=1}^{2} w_{k}\left(z_{k}-\bar{z}\right)^{2}}{\sum_{k=1}^{n} \Sigma_{i=1}^{n} w_{k i}\left(z_{k i}-z_{k i}\right)^{2}}$

Where

$Z_{k i}=\left|X_{k i}-\bar{X}_{k}\right|$

$\bar{Z}_{k}=\frac{\sum_{i=1}^{i_{k}} w_{k i} Z_{k i}}{w_{k}}$

$\bar{Z}=\frac{\sum_{k=1}^{z} w_{h} z_{k}}{w_{1}+w_{2}}$

$X_{k i}$ Value for the ith case of group k

$W_{k i}$ Weight for the ith case of group $\mathrm{k}$

$n_{k}$ Number of cases in group $\mathrm{k}$

$W_{k}$ Sum of weight of cases in group $\mathrm{k}$

\section{Logistic regression}

This procedure was used to determine the effect of socio-economic characteristics of the households on state of the forest reserves. The parameters of the model were estimated with the maximum likelihood estimation technique. A binary response model "degraded forest" and "non-degraded forest" was specified and estimated logistically. The logit specification is suited to models where the dependent variable is dichotomous, which in this case are the forest state that are degraded and non-degraded. The logit specification then provided a model of observing the probability of factors that influenced forest degradation or not.

Following Gujarati (1988), the model is specified as follows:

$$
\begin{aligned}
& P\left(Y_{i=m}\right)=\frac{1}{1+\mathrm{e}^{-z}} \\
& \frac{P}{1-P}=e^{z} \\
& 1-P=1-\frac{1}{1+\mathrm{e}^{-z}}
\end{aligned}
$$


Given that $\Omega=\frac{p}{1-p}$

Then $\Omega=e^{g}$

$\Omega=\frac{F}{1-F}$

$P=$ Probability of occurrence of the dependent variable

$Y_{i}=$ Dependent variable corresponding to certain value, $m$.

$\boldsymbol{z}=$ Predictor variable (linear combination of the conversion factors)

$e=$ Base of natural logarithm and

$\Omega=$ Odd of the evaluative factors

occurring for each explicative factor

Assuming $\mathrm{Z}$ is a linear function of a set of predictor variable, then,

$Z=\beta_{0}+\beta_{1} X_{1 i}+\beta_{2} X_{2 i}+\cdots \ldots+\beta_{k} X_{k i}$

If equation (9) holds then;

$\Omega=e^{\beta_{0}+\beta_{1} X_{1 i}+\beta_{2} X_{2 i}+\cdots, \beta_{n i}+\beta_{h i} Z_{h i}}$

In this study, $P\left(Y_{i z m}\right)$ is the probability of the forest state being degraded; these are ascribed 1; and 0 otherwise.

The logistic regression model is given as:

$\Omega=e^{\beta_{0}+\beta_{1} X_{1 \mathrm{i}}+\beta_{2} X_{z i}+\cdots n_{\mathrm{u}}+\beta_{k} Z_{k i}}$

The explicative factors are as listed below and operationalized.

$Y_{i}=$ forest state (1 if degraded forest, 0 otherwise),

$\beta_{i}=$ Unknown parameters to be

estimated, $e=$ error term while $x_{i}$ ranges from 1-14.

$x_{1}=$ Age (years),

$x_{2}=$ Gender of household heads (Male $=$

1, $0=$ Otherwise),

$x_{3}=$ Number of household members

working and earning income,

$x_{4}=$ Number of children in the

household,

$x_{5}=$ Number of youth in the household,

$x_{6}=$ Number of middle aged in the household, $x_{7}=$ Number of aged in the household, $x_{\mathrm{g}}=$ Forest income (Naira),

$x_{9}=$ Earning income from tree crops ( 1 if Yes, 0 otherwise),

$x_{10}=$ Earning income from livestock (1 if Yes, 0 otherwise),

$x_{11}=$ Earning income from hunting (1 if Yes, 0 otherwise),

$x_{12}=$ Earning income from NTFPs (1 if Yes, 0 otherwise),

$x_{13}=$ Earning income from artisan (1 if Yes, 0 otherwise),

$x_{14}=$ Earning income from trading (1 if Yes, 0 otherwise).

\section{Marginal Effects after Logistic Regression}

Marginal effects measure the expected instantaneous change in the dependent variables as a function of a change in a certain explanatory variable while holding other co-variates constant (SAS, 2011). It is thus a means of interpreting the effects of the predictor variables on the dependent variable. For a logistic regression model, the marginal effect of a change in the $P(Y=1)$ changes when $X$ increases by 1 unit. As such, the marginal effect of a change in the explanatory variable on the forest degradation state is given as:

$\delta_{j k}=\frac{\delta P_{i}}{\delta x_{K}}=p_{j}\left(\beta_{j}-\Sigma p_{j} \beta_{j}\right)$

$P_{j}=$ probability of attaining the mean incidence of forest degradation value

$\delta_{j k}=$ impact of a variation in the predictor variable $x_{k}$ on the probability of occurrence

\section{Odds Ratio}

The odds ratio is a statistical measure defined as the ratio of the odds of an event occurring in one group to an event occurring in another group; for instance, 
a dichotomous classification. It is a summary measure of the relationship between two variables or dichotomous classification and it tells us how better the odds are for the occurrence of a certain event. The odds ratios are particularly useful when dealing with dummy variables to answer some policy questions such as how likely will a degraded forest affect income of households that depends on it compared to that of households in an Non degraded forest?

Assume the

odds for group $1=$ odds $1=p / 1-p$ and the

odds for group $2=$ odds $2=q / 1-q$ ; where $p$ and $q$ are probabilities for group 1 and 2, respectively. odds ratio $=$ odds $1 /$ odds $2, \quad$ but considering that $\ln \left(\frac{p}{1-p}\right)=\log i t(p)$ and

$\ln \left(\frac{q}{1-q}\right)=\operatorname{logit}(q)$, it follows that the

log odds ratio $=\operatorname{logit}(p)-\operatorname{logit}(q)$

. Therefore, the odds ratio may be taken as the antilogarithm of [logit $(p)-\operatorname{logit}(q)]$ or alternatively as the antilogarithm of the slope of the logit regression, one unit apart of two different values of the predictor (Mukherjee et al., 1998).

\section{Results and Discussion}

Different forest based livelihood and returns were investigated in this study. The result is presented in Table 1 . The Table indicated that forest communities depend on the forest for arable and tree crop production, livestock keeping, NTFPs collection such as bush meat, herbs, firewood, forest fruit and other NTFPs. Products from these activities are either consumed or sold to generate income. The Table further indicates a regular pattern of greater income generation than consumption of all the forest products except for forest herbs, bush meat and other NTFPs in the nondegraded as against the degraded forests. This on its own lends credence to the fact that the forest is a major asset that the forest communities depend on for exchange of other products and services that the forest could not primarily provide (FAO, 2002). A closer look at the result revealed that the products that were consumed more than being sold were those whose substitute may be more expensive to buy. This is the case behind the increased consumption of bush meat and other NTFPs such as snails, mush room which were the main sources of protein that cannot be jettisoned for fish or beef coming from town and therefore will be more expensive for them to buy. The same explanation could be proffered for herbs that are relied upon for healthcare.

Further exploration of the Table however shows disparity in the livelihood returns across the non-degraded and degraded forest. These differences were affirmed in Table 2 to be in arable and tree crop production with the degraded forest having more return of $\$ 2200.13^{1}$ and $\$ 1675.30$ as against $\$ 2305.75$ and $\$ 975.25$ per acre per year respectively in a non-degraded forest. This may be made possible by removal of some trees to increase population density of the crops per acre of forest land.

${ }^{1} \$ 1=\$ 157.27$ (2013 average exchange rate at central bank of Nigeria) 
However, returns associated with other set of forest based livelihood per year were higher in a non-degraded than a degraded forest. Significant differences were observed in the returns associated with bush meat hunting ( $\$ 35.54$ and $\$ 9.54)$, collection of firewood (\$155.94 and \$22.06), forest fruit (\$138.32 and $\$ 9.38$ ) and other NTFPs (\$44.47 and $\$ 4.43$ ) in a non-degraded and degraded forest respectively. In other words, a nondegraded forest will give more bush meat, firewood, forest fruit and other NTFPs. Obviously, the protein requirement of the forest communities can be met if the forest is not degraded as most of the protein supplying forest products were being consumed and not sold.

\section{Factors Influencing Forest Degradation}

The result of the Logistic analysis used to identify the factors influencing forest degradation is presented in Table 3 . The likelihood ratio of -55.395127 is significant at $1 \%$ indicating the overall significance and goodness of fit of the model. Out of the fourteen explanatory variables included in the model, five were significant in explaining the state of the forest reserve whether degraded or nondegraded. The odd ratios of the variables are also presented in Table 3 .

The results show that gender of respondents has a positive and significant effect on the state of the forest reserve. This implies that male respondents are more likely to contribute to forest degradation when compared with their female counterparts. The marginal effect value showed that the likelihood of degrading the forest is $36.25 \%(0.3625)$ higher in a male as against a female forest dweller. This may be due to the fact that the male are more involved in hunting, cutting and burning of trees within the forest. This is against the findings of Bongers and Tennigkeit (2010), that men are more likely to be able to reduce their exploitation of forest resources because they have more employment and business opportunities elsewhere and thus this potentially makes women the major agents of forest degradation. But according to Nadkarni (2000), who explained that women have played an enthusiastic role in preventing overexploitation of forests by commercial interests, and that women are so closely linked with natural resources such that they represent a constructive and protective force for the environment and therefore can play a crucial role in turning vicious circles into virtuous ones.

Also, the number of household members working and earning income is significantly negative and thereby reducing forest degradation. The marginal effect result indicated that a unit increase in the number of household members working and earning income will decrease the likelihood of degrading the forest by 7\% (0.0726). This corroborates with the findings of Folayan and Bifarin, (2009) that should the number of people that take forest business as their primary occupation decrease; there would be drastic decrease in forest activities.

Furthermore, increasing number of children in the household had a positive and significant effect on forest degradation. This showed that the more the number of children in the household the greater the likelihood of such household contributing to forest degradation. The marginal effect coefficient 0.0544 implied that a unit increase in number of children in the 
household increases forest degradation status by $5 \%$. This is in line with the findings of Folayan and Bifarin (2009), who explained that reduction in family size will reduce the number of investors in forest business and thus decrease the forest activities by forest inhabitants.

The results also showed that those respondents that earn income from tree crops and from hunting have a positive and significant effect on the forest degradation state. Results of the marginal effects revealed that the likelihood of these sets of respondents degrading the forest were $13 \%(0.1314)$ and $29 \%$ (0.2913) respectively. This compares favourably with the observations of Miya et al., 2012 that deforestation and forest degradation is ultimately driven by the demand for timber and other forest products. Also, Dallu (2006) listed the threats currently facing forest management as illegal harvesting and trade in timber and other forest products. This emphasizes the impacts of deforestation and uncontrolled/unsustainable hunting in the degradation of the forest.

The result of the odds ratio showed that the number of household members working and earning income is the most important factor that contributes to the state of the forest. An individual increase in the number of household members working and earning income reduces the odds of forest degradation by $49.78 \%$ (1 -0.5022 ).

\section{Conclusion and Recommendation}

This study concludes that forest degradation leads to a significant reduction of the productive capacity of the forest thereby limiting the consumptive and livelihood benefits derivable from such. The factors that contribute to forest degradation were gender (male), unemployment (nonworking member of household), unplanned birth (increasing number of children per household), and livelihood activities (tree crop farming and hunting). Therefore, the study recommends that efforts should be made by government, non-governmental organizations, donor agencies and corporate bodies at creating jobs and empowerment particularly the male forest community dwellers so as to take the pressure of over extraction off the forest. Also, birth control mechanisms and school enrolment should be publicized around the forest communities so as to minimize the number of children per household and also ensure that children have lesser time in extracting the forest. Furthermore, strong and participatory forest management practices should be encouraged to ensure that tree crop farming and hunting are monitored and done without hurting the forest. 
Forest Degradation and Livelihood.................OLAREWAJU et al.

Table 1: Livelihood Returns in Non-degraded and Degraded Forests per year

\begin{tabular}{|c|c|c|c|c|}
\hline Income source & Forest State & $\begin{array}{ll}\text { Livelihood } & \text { returns } \\
(\$) & \end{array}$ & Consumption (\$) & Total worth $(\$)$ \\
\hline \multirow[t]{2}{*}{ Arable crops } & $\begin{array}{l}\text { Non } \\
\text { degraded }\end{array}$ & $1,846.05$ & 354.08 & 2200.13 \\
\hline & Degraded & $1,923.84$ & 381.91 & 2305.75 \\
\hline \multirow{2}{*}{ Tree crop } & $\begin{array}{l}\text { Non } \\
\text { degraded }\end{array}$ & $1,565.65$ & 109.66 & 1675.30 \\
\hline & Degraded & 854.42 & 120.81 & 975.23 \\
\hline \multirow[t]{2}{*}{ Livestock } & $\begin{array}{l}\text { Non } \\
\text { degraded }\end{array}$ & 19.08 & 4.38 & 23.45 \\
\hline & Degraded & 0.21 & 1.91 & 22.89 \\
\hline \multirow{2}{*}{ Bush meat } & $\begin{array}{l}\text { Non } \\
\text { degraded }\end{array}$ & 31.27 & 4.27 & 35.54 \\
\hline & Degraded & 0.00 & 9.54 & 9.54 \\
\hline \multirow{2}{*}{ Forest herbs } & $\begin{array}{l}\text { Non } \\
\text { degraded }\end{array}$ & 1.04 & 2.08 & 3.13 \\
\hline & Degraded & 0.00 & 0.48 & 0.48 \\
\hline \multirow{2}{*}{$\begin{array}{l}\text { Firewood/ } \\
\text { Charcoal }\end{array}$} & $\begin{array}{l}\text { Non } \\
\text { degraded }\end{array}$ & 150.62 & 5.32 & 155.94 \\
\hline & Degraded & 19.08 & 2.99 & 22.06 \\
\hline \multirow{2}{*}{ Forest fruit } & $\begin{array}{l}\text { Non } \\
\text { degraded }\end{array}$ & 117.27 & 21.06 & 138.32 \\
\hline & Degraded & 7.63 & 1.75 & 9.38 \\
\hline \multirow[t]{2}{*}{ Other NTFPs } & $\begin{array}{l}\text { Non } \\
\text { degraded }\end{array}$ & 7.41 & 37.06 & 44.47 \\
\hline & Degraded & 0.89 & 3.54 & 4.43 \\
\hline
\end{tabular}


Table 2: Test of Differences in Mean of Livelihood returns in non-degraded and Degraded Forests per year

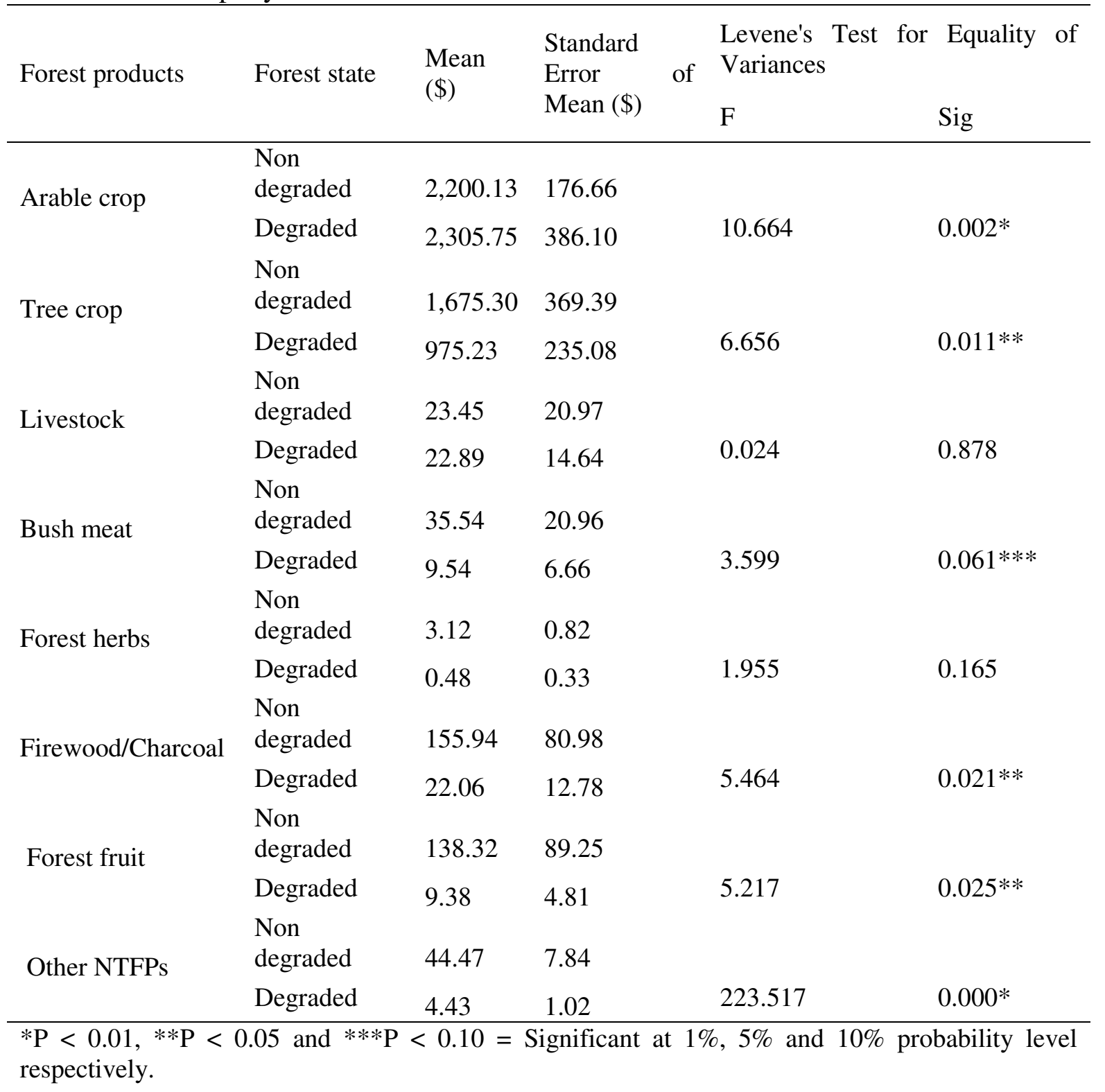


Forest Degradation and Livelihood.................0LAREWAJU et al.

Table 3: Factors Influencing Forest Degradation

\begin{tabular}{|c|c|c|c|}
\hline Variables & Coefficient & Marginal effect & Odds ratio \\
\hline Age & -0.0125 & -0.0013 & -0.9876 \\
\hline Gender & $3.4399 * * *$ & $0.3625^{* * *}$ & $31.1842 * * *$ \\
\hline $\begin{array}{l}\text { Working household } \\
\text { member }\end{array}$ & $-0.6886 * * *$ & $-0.0726 * * *$ & $-0.5022 * * *$ \\
\hline No of Children & $0.5161 * * *$ & $0.0544 * * *$ & $1.6755^{* * *}$ \\
\hline No of Youth & 0.1777 & 0.0187 & 1.1945 \\
\hline No of middle aged & -0.2875 & -0.0302 & -0.7501 \\
\hline No of Aged & 0.3774 & 0.0398 & 1.4584 \\
\hline Forest income & -0.0088 & -0.0094 & -0.9999 \\
\hline \multicolumn{4}{|l|}{ Livelihood dummies } \\
\hline Tree crop & $1.2466^{* *}$ & $0.1314 * *$ & $3.4784 * *$ \\
\hline Livestock & 0.0865 & 0.0091 & 1.0903 \\
\hline Hunting & $2.7643 * * *$ & $0.2913 * * *$ & $15.8677 * * *$ \\
\hline NTFPs & -0.1861 & -0.0196 & -0.8302 \\
\hline Artisan & 0.0427 & 0.0045 & 1.0437 \\
\hline Trading & -1.4132 & -0.1489 & -0.2434 \\
\hline Constant & $-6.2132 * * *$ & & \\
\hline Log likelihood & -55.3951 & & \\
\hline LR Chi square & 73.09 & & \\
\hline Pseudo R-square & 0.3975 & & \\
\hline
\end{tabular}

\section{References}

Adamson, K.Y (1996). Towards an Environmental Action Plan for Ogun State. Federal Republic of Nigeria Federal Environmental Protection Agency Draft Final Report. Ogun State Ministry of Forestry (2014). Ogun State Forestry Monitoring and Control system retrieved on June 15th 2014 from

http://ogunforestryoperations.com.n g/aboutus.php

Adewuyi S.A., Adebayo A.O., Aderinboye, R.Y. and Bada, B.S. (2009). Ogun State Diagnostic Survey Report. Institute of Food Security, Environmental Resources and Agricultural Research, University of Agriculture, Abeokuta From http://www.unaab.edu.ng/attachmen ts/OgunReport3.pdf (retrieved on 16/08/2016)

Arjunan, M., Puyravaud, J.-Ph. and Davidar, P. (2005). The impact of resource collection by local communities on the dry forests of the Kalakad-Mundanthurai Tiger Reserve, India. Tropical Ecology 46: 135-143.

Banerjee, A. and Madhurima, C. (2013). Forest degradation and livelihood of local communities in India: A human rights approach. Journal of Horticulture and Forestry, Vol. 5(8): 122-129.

Blalock, H.M. (1972). Social statistics. New York: McGraw-Hill

Bongers, F. and Tennigkeit, T. (2010). Degraded Forests in Eastern Africa: Management and 
Restoration. Published by Mapset Ltd, Gateshead, UK. ISBN 978-184407-967-0.pp. 316.

Chambers, R. (1995). Poverty and livelihoods: whose reality counts? Environment and Urbanization 7: 173

Dallu, A.I.M. (2006). Forest Resources Management in Tanzania. Forestry and Beekeeping Division, Ministry of Natural Resources and Tourism. $17 \mathrm{pp}$.

Davidar, P., Sahoo, S., Mammen, P.C., Acharya, P., Puyravaud, J.P., Arjunan, M., Garrigues, J.P. and Roessingh, K. (2010). Assessing the extent and causes of forest degradation in India: Where do we stand? Biological Conservation 143: 2937-2944.

FAO (2002). Global Forest Resources Assessment 2000 - Main Report. FAO Forestry Paper No.140. Food and Agriculture Organization of the United Nations, Rome.

Folayan, J.A. and Bifarin, J.O. (2009). Forestry Potentials in Employment Generation in Akure-Ofosu Forest Reserve of Ondo State, Nigeria. International Journal of Creativity and Technical Development, 1(1-3): 66-77.

Gujarati, D.N. (1988). Basic Econometrics. 2nd edition. New York: McGraw-Hill. Pp. 98-102.

Harris, F. and Mohammed, S. (2003). Relying on nature: Wild foods in Northern Nigeria. Ambio 32: 24-29.

Karanth, K.K., Curran, L.M. and Reuning-Scherer, J.D. (2006). Village size and forest disturbance in Bhadra Wildlife Sanctuary, Western Ghats, India. Biological Conservation, 128: 147-157.
Maikhuri, R.K., Semwal, R.L., Rao, K.S., Saxena, K.G. and Das, A.K. (2001). Indigenous techniques of agricultural soil fertility maintenance in the Central Himalaya. Ecol. Environ. Cons, 7(1): 15-20.

Miya, M., Ball, S.M.J. and Nelson, F.D. (2012). Drivers of Deforestation and Forest Degradation in Kilwa District. Mpingo Conservation \& Development Initiative. Pp.1-34.

Mukherjee, C., White, H. and Wuyts, M. (1998). Econometrics and Data Analysis for Developing Countries. London; New York, Routledge.

Nadkarni, M.V. (2000). Poverty, Environment, Development: A Many-Patterned Nexus, Economic and Political Weekly, Vol. 35, No. 14 (Apr. 1-7), pp. 1184-1190.

Ogun State Ministry of Forestry (2014). http://www.ogunstate.gov.ng/minist ries/ministry-of-forestry.html. Accessed on $10^{\text {th }}$ of July, 2014.

Ogundele, F.O., Odewumi, S.G. and Bello, G. (2013). Mophometric Description of Gullies Developing on Coastal Plain Formations around Yewa South and Ipokia in Ogun State South-West Nigeria. Journal of Geography and Geology, 5(1): 126-137.

Onuche, P. (2011). Non-Timber Forest Products (NTFPs): A Pathway for Rural Poverty Reduction in Nigeria. International Journal of Economic Development Research and Investment, 2(2): 28-37.

Sagar, R. and Singh, J.S. (2004). Local plant species depletion in a tropical dry deciduous forest of Northern India. Environmental Conservation 31: 55-62. 
SAS Institute Inc. (2011). Base SAS $^{\circledR} 9.3$ Procedures Guide. Cary NC: SAS Institute Inc. ISBN 978-1-60764895-6.

Silori, C. S. and Mishra, B. K. (2001). Assessment of livestock grazing pressure in and around the elephant corridors in Mudumalai Wildlife Sanctuary. Biodiversity and Conservation 10: 2181-2195.

Tavani, R., Saket, M., Piazza, M., Branthomme, A. and Altrell, D. (2009). Case Studies on Measuring and Assessing Forest Degradation. Measuring and Monitoring Forest Degradation through National Forest Monitoring Assessment
(NFMA). Forest Resources Assessment, Working Paper 172. Tewari, D.D. (2012). Promoting nontimber forest products (NTFPs) to alleviate poverty and hunger in rural South Africa: A reflection on management and policy challenges. African Journal of Business Management, 6(47): 11635-11647.

World Resources (2005). The Wealth of the Poor - Managing Ecosystems to Fight Poverty. World Resources Institute (WRI) in collaboration with United Nations Development Programme and World Bank, 2005. Washington, DC: WRI. 